\title{
Geographical distribution of the giant honey bee Apis laboriosa Smith, I87I (Hymenoptera, Apidae)
}

\author{
Nyaton Kitnya', M.V. Prabhudev ${ }^{2,3}$, Chet Prasad Bhatta ${ }^{4,5}$, Thai Hong Pham ${ }^{6}$, \\ Tshering Nidup ${ }^{7}$, Karsing Megu², Jharna Chakravorty', \\ Axel Brockmann ${ }^{2}$, G.W. Otis ${ }^{8^{*}}$
}

I Department of Zoology, Rajiv Gandhi University, University Road, Itanagar, Papum Pare, Arunachal Pradesh 791112, India 2 National Centre for Biological Sciences - Tata Institute of Fundamental Research, Bellary Road, Bangalore 560065, Karnataka, India 3 Department of Biosciences, University of Mysore, Krishnaraja Boulevard Road, K.G. Koppal, Mysore 570006, Karnataka, India 4 Department of Ecology and Evolutionary Biology, University of Kansas, 1200 Sunnyside Avenue, Lawrence, KS 66045, USA 5 Department of Biology, Radford University Carilion, 101 Elm Avenue SE, Roanoke, VA 24013, USA 6 Research Center for Tropical Bees and Beekeeping, Vietnam National University of Agriculture, Trau Quy - Gia Lam - Ha Noi, Vietnam 7 Department of Environment \& Life Sciences, Sherubtse College, Royal University of Bhutan, Kanglung, Trashingang, Bhutan 8 School of Environmental Sciences, University of Guelph, Guelph, Ontario N1G 2W1, Canada

Corresponding author: Nyaton Kitnya (nyatonkitnya@gmail.com)

Academic editor: Michael S. Engel | Received 6 January 2020 | Accepted 29 April 2020 | Published 22 July 2020

http://zoobank.org/D34D5192-F7DA-46F8-A9F7-61EE3F6263E9

Citation: Kitnya N, Prabhudev MV, Bhatta CP, Pham TH, Nidup T, Megu K, Chakravorty J, Brockmann A, Otis GW (2020) Geographical distribution of the giant honey bee Apis laboriosa Smith, 1871 (Hymenoptera, Apidae). ZooKeys 951: 67-81. https://doi.org/10.3897/zookeys.951.49855

\begin{abstract}
Worldwide pollinator declines have dramatically increased our need to survey and monitor pollinator distributions and abundances. The giant honey bee, Apis laboriosa, is one of the important pollinators at higher altitudes of the Himalayas. This species has a restricted distribution along the Himalayas and neighbouring mountain ranges of Asia. Previous assessments of its distribution, published more than 20 years ago, were based on museum specimens. Since then, 244 additional localities have been revealed through field trips by the authors, publications, and websites. We present a revised distribution for A. laboriosa that better defines its range and extends it eastward to the mountains of northern Vietnam,
\end{abstract}

\footnotetext{
* Co-senior authors
}

Copyright Nyaton Kitnya et al. This is an open access article distributed under the terms of the Creative Commons Attribution License (CC BY 4.0), which permits unrestricted use, distribution, and reproduction in any medium, provided the original author and source are credited. 
southward along the Arakan Mountains to west-central Myanmar, into the Shillong Hills of Meghalaya, India, and northwestward in Uttarakhand, India. This species is generally found at elevations between 1000-3000 m a.s.l.. In northeastern India A. laboriosa colonies occur during summer at sites as low as $850 \mathrm{~m}$ a.s.l. and some lower elevation colonies maintain their nests throughout the winter. Finally, we report three regions in Arunachal Pradesh, India, and nine locations in northern Vietnam, where we observed workers of $A$. laboriosa and $A$. dorsata foraging sympatrically; their co-occurrence supports the species status of Apis laboriosa.

\section{Keywords}

Apidae, Apis dorsata, conservation, Himalayas, pollinator, sympatry

\section{Introduction}

The Himalayan giant honey bee $A$. laboriosa is a spectacular but poorly understood species, in large part because it usually nests on inaccessible cliff faces in the Himalaya Mountains (Cronin 1979; Sakagami et al. 1980; Roubik et al. 1985; Underwood 1990a; Joshi et al. 2004; Gogoi et al. 2017). The first specimen was collected in the mountainous regions of western Yunnan and named by Frederick Smith (Moore et al. 1871), who noted several characteristics that he felt distinguish $A$. laboriosa from lowland $A$. dorsata. This taxon was subsequently ignored until Maa (1953) undertook his reassessment of honey bee taxonomy. He stated its distribution as "India (Sikkim; Assam); China (western Yunnan). Probably also occurring in N. Burma". Sakagami et al. (1980) provided the first detailed descriptions of the morphology, biology, and geography of $A$. laboriosa and provided strong evidence that it should be recognized as a distinct species different from the lowland giant honey bee $A$. dorsata. They also presented a range map depicting 22 localities along several rivers that extend into the Himalayas of Nepal. They noted that records outside Nepal were "scarce" and provided just one locality in "Tibet" and four in Arunachal Pradesh (Sakagami et al. 1980: p. 63). Interestingly, Sakagami et al. (1980) mentioned one site (Denling Forest, Kameng Div., Arunachal Pradesh, 229 m a.s.l.) from which both $A$. laboriosa and $A$. dorsata had been collected, indicating that in some parts of Asia these two forms occur sympatrically.

The most recent range map of $A$. laboriosa (Otis 1996) was published more than 20 years ago. Although Otis (1996) compiled all locality data available at that time, there were obvious gaps (e.g., in Bhutan, northeastern India, northern Myanmar, Laos, and Vietnam). Since then, the number of verified reports has increased rapidly due to additional fieldwork, new publications and postings of photos and videos by naturalists on iNaturalist and other websites.

We present here an updated distribution map of $A$. laboriosa and present additional evidence that $A$. laboriosa and its sister species $A$. dorsata co-occur in several locations in Asia. 


\section{Materials and methods}

\section{Identification of Apis laboriosa}

The Himalayan giant honey bee $A$. laboriosa differs significantly from the giant honey bee A. dorsata of mainland Asia in many characters noted by Sakagami et al. (1980). Sakagami et al. (1980) could always distinguish the two taxa on the basis of thoracic hair colour, which was "tawny yellow" in laboriosa and "mostly dark" in dorsata. Additionally, the first two gastral tergites of laboriosa are black (grey in callow adults); in dorsata of mainland Asia, they are orange-brown (pale yellow in callows; Fig. 1). Several genetic analyses indicate these two taxa have diverged sufficiently to consider A. laboriosa to be a distinct species (Arias and Sheppard 2005; Raffiudin and Crozier 2007; Lo et al. 2010; Chhakchhuak et al. 2016; Takahashi et al. 2018). Despite these many differences, Engel (1999), in the most recent reassessment of Apis taxonomy, considered $A$. laboriosa to be a subspecies of $A$. dorsata that may be deserving of species status. Because of substantive differences in drone morphology (NK and GWO, unpubl. data) and distinct morphometric differences (NK, unpublished data) between the two taxa collected sympatrically in northeastern India (this study), we are confident that $A$. laboriosa is a distinct species and refer to it as such below. For this study, we identified specimens and photos of the bees on the basis of thoracic hair and abdominal colour (Sakagami et al. 1980).

\section{Data collection}

The starting point for this project was the list of collection localities reported by Otis (1996) who summarized the 105 records available from museum specimens and literature up to that time (Maa 1953; Sakagami et al. 1980; Kuang and Li 1985; Roubik et al. 1985; Underwood 1990a; Batra 1996).

Subsequently, Trung et al. (1996) remarkably extended the distribution of A. laboriosa well into Vietnam. Additional localities in Vietnam have been detected in seven northern provinces by THP. Between 2001-2008 he sought information on cliffnesting honey bees at high elevations (> $900 \mathrm{~m}$ a.s.l.) in northern Vietnam from beekeepers, honey-hunters, and others living in those regions. For those who responded positively, he visited the region and showed informants photos and specimens of $A$. laboriosa and $A$. dorsata. If the information suggested the bees were $A$. laboriosa, then he contacted them to visit the nesting cliff to observe the colonies and collect specimens, if possible, for verification.

$\mathrm{CPB}$ collected specimens from many parts of Nepal to analyze genetic variability within A. laboriosa; he contributed 17 additional localities in Nepal. Joshi et al. (2004) reported numerous localities $(N=54)$ in the Kaski District of Nepal.

TN contributed 29 new localities in Bhutan in addition to the two localities he and his colleague had reported earlier (Nidup and Dorji 2016). 

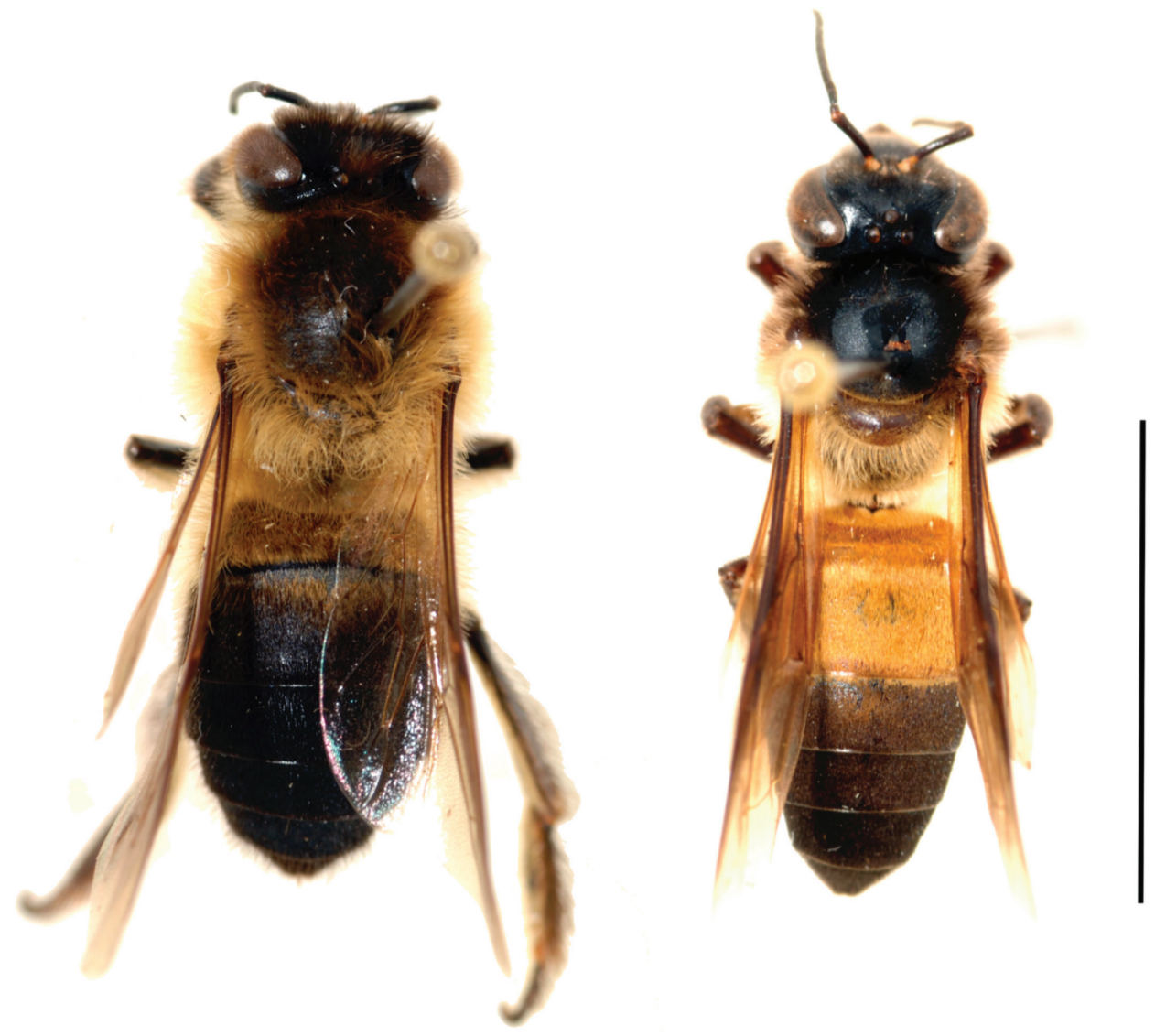

Figure I. Apis laboriosa and Apis dorsata worker bees. A. laboriosa (left) has a completely dark abdomen and long golden thoracic hairs. A. dorsata (right) has several orange or yellow anterior abdominal segments and dark thoracic hairs. Details for the specimens photographed: A. laboriosa, collected by BA Underwood, Kaski District, Nepal, 1860 m, 8 v 1984 (Nest 6-8); A. dorsata, collected by GW Otis, Serdang, Selangor, Malaysia, $3.00 \mathrm{~N}, 101.68 \mathrm{E}, 8$ ii 1989 . Scale bar: $1 \mathrm{~cm}$.

Within India, a team (NK, MVP, KM, JC, and AB), in their fieldwork on $A$. laboriosa, have added numerous localities from northern and northeastern India. Several authors have reported sites where this bee species occurs in Uttarakhand, India (Gupta 2004; Joshi et al. 2008; Joshi et al. 2016). Additional localities were reported from Arunachal Pradesh, India, by Gogoi and colleagues (Gogoi et al. 2017; Tayeng and Gogoi 2018). The Nagaland Beekeeping and Honey Mission (NBHM) has collated information on the "Rock bee" within the state of Nagaland (Team NBHM 2015). Similarly, Chhakchhuak et al. (2016) reported a nesting cliff in Murlen in Mizoram. Vivek Sarkar (pers. comm.) shared three localities in the highlands of Meghalaya.

Hliang Min Oo (pers. comm.) located cliffs inhabited by -50 colonies of $A$. laboriosa in the mountains of western Myanmar. He shared photos that are clearly of that 
species. Anne Schooffs (pers. comm.) and Kevin Kamp (pers. comm.) contributed their observations in Laos. Similarly, Xin Zhou and Li Fei Qui (pers. comm.) shared details of their 2019 collection locality in Yunnan, China. Cao and colleagues already reported two localities in Yunnan in 2012 (Cao et al. 2012).

We recognize that some records are stronger than others. Consequently, we have distinguished four categories of records:

1. Observations by the authors. These include observations of nests on rock cliffs and of foragers (many of which were collected for further study) at flowers and human urine.

2. Internet records. GWO searched the internet extensively for photographs of bees and bee nests that could be definitively identified as A. laboriosa based on abdominal and thoracic hair colour. This search included websites and images retrieved from Google searches of "Apis laboriosa", "cliff bee", "giant honey bee + (country name)", and "honeyhunting + (country name)", with the search including all mountainous countries in Asia from Pakistan east to Vietnam; records of A. laboriosa posted to iNaturalist (www.inaturalist.org), all of which were verified as A. laboriosa by John Ashcher, National University of Singapore; and the Nature Picture Library (www.naturepl. com). When details were lacking in the post (locality, date, etc.), the people who had posted the sightings were contacted directly.

3. Records from published reports. Scientists who mentioned A. laboriosa in their works were presumably aware of the differences between $A$. laboriosa and $A$. dorsata. We trusted their identifications, i.e., in most cases we did not attempt to contact them to verify their ability to distinguish $A$. laboriosa.

4. Personal observations of naturalists and honey-hunters that cannot be verified by other means. Honey-hunters, through their extensive experiences, generally distinguish between $A$. laboriosa (the "cliff bee" with a black abdomen) and $A$. dorsata (the "tree bee" with the orange abdomen). In cases where they differentiated these two forms, we included the localities they reported. We have used different coloured symbols for these different categories of information on our revised distribution map, with category 1 records being the uppermost layer on the map. Some lower category localities are obscured by stronger higher category records.

We obtained additional bee localities by searching for photos on the internet and literature about the yellow-rumped honeyguide (Indicator xanthonotus). The honeyguides (Indicatoridae) are one of the few taxa of animals known to be able to digest wax (Downs et al. 2002). Males of this Himalayan species defend empty combs of $A$. laboriosa, then mate with females that arrive to feed on beeswax (Cronin and Sherman 1976; Cronin 1979; Underwood 1992). The geographic and elevational distributions of the yellow-rumped honeyguide (Bird Life International; www.birdlife.org) closely match those of $A$. laboriosa (this study). We performed Google and iNaturalist searches for "yellow-rumped honeyguide" and "Indicator xanthonotus". Localities for the honeyguide at elevations $>1500 \mathrm{~m}$ a.s.l. that included depictions or descriptions of them associated with open-nesting honey bees have been included. 
In our personal field work, we used global positioning system (GPS) instruments (i.e., eTrex 20, Garmin Ltd, Olathe, Kansas, USA) to document locations. When that was not possible or we had only a locality name (e.g., many of the localities reported in publications), we searched for them using Google Maps. Occasionally due to changes in names or spellings, we undertook lengthy web searches to find the current names. Not all records could be located (e.g., "Pamir, Arunachal Pradesh" reported by Sakagami et al. 1980). Latitude and longitude coordinates are presented in degrees and decimal degrees (Suppl. material 1: Table S1).

We plotted locality records using ArcGIS Desktop 10.3 of ESRI (Environmental System Research Institute, www.esri.com). The boundary maps of the region of interest were extracted from Google Earth Pro (v7.3) as a Keyhole Markup language Zipped $(\mathrm{kmz})$ file and imported into ArcGIS.

\section{Results}

\section{Revised distribution of Apis laboriosa}

We have compiled a list of 349 localities of Apis laboriosa foragers or nests (Suppl. material 1), of which we were able to locate and map 345 (see Fig. 2). The mapped localities are as follows: Bhutan (57), China (48), India (92), Laos (3), Myanmar (4), Nepal (132), and Vietnam (13). The species is distributed almost continuously over a distance of $>2500 \mathrm{~km}$ along the Pan-Himalaya region from Uttarakhand, India, eastward through Nepal, Sikkim and northern West Bengal (Darjeeling), Bhutan, northeastern India, Yunnan and southern Tibet in China, and the northern portions of Myanmar, Laos, and Vietnam. We report for the first time numerous records southward along the Arakan Mountains in eastern Arunachal Pradesh, Nagaland, Manipur, and Mizoram (India) to Matupi in west-central Myanmar. We have also verified that it occurs in the Shillong Hills of Meghalaya.

\section{Elevational distribution of Apis laboriosa}

Localities range in elevation from approximately $230-4270 \mathrm{~m}$ a.s.l. Nearly all records (94\%) fall within the altitudinal range of 500-3500 m a.s.l., and $77.2 \%$ were between 1000-3000 m a.s.l. (Fig. 3). We confirmed the observation of Sakagami et al. (1980) that A. laboriosa occurs at lower elevations in Arunachal Pradesh than at sites further west in Bhutan, Nepal, and Uttarakhand, India. The lowest recorded elevation was reported by Sakagami et al. (1980), at 229 m a.s.l. in "Denling Forest", western Arunachal Pradesh, India. We were unable to find that locality to map it. However, we (NK, KM, and GWO) observed foragers at a similar elevation (233 m a.s.l.) in central Arunachal Pradesh. Relatively few records are from sites higher than $3000 \mathrm{~m}$ a.s.l. and the records from Trubuking Kharka, Nepal (4100 m a.s.l.; Sakagami et.al.1980) and a specimen in the Natural History Museum, London (4267 m a.s.l.) are the only observations above $4000 \mathrm{~m}$ a.s.l. 


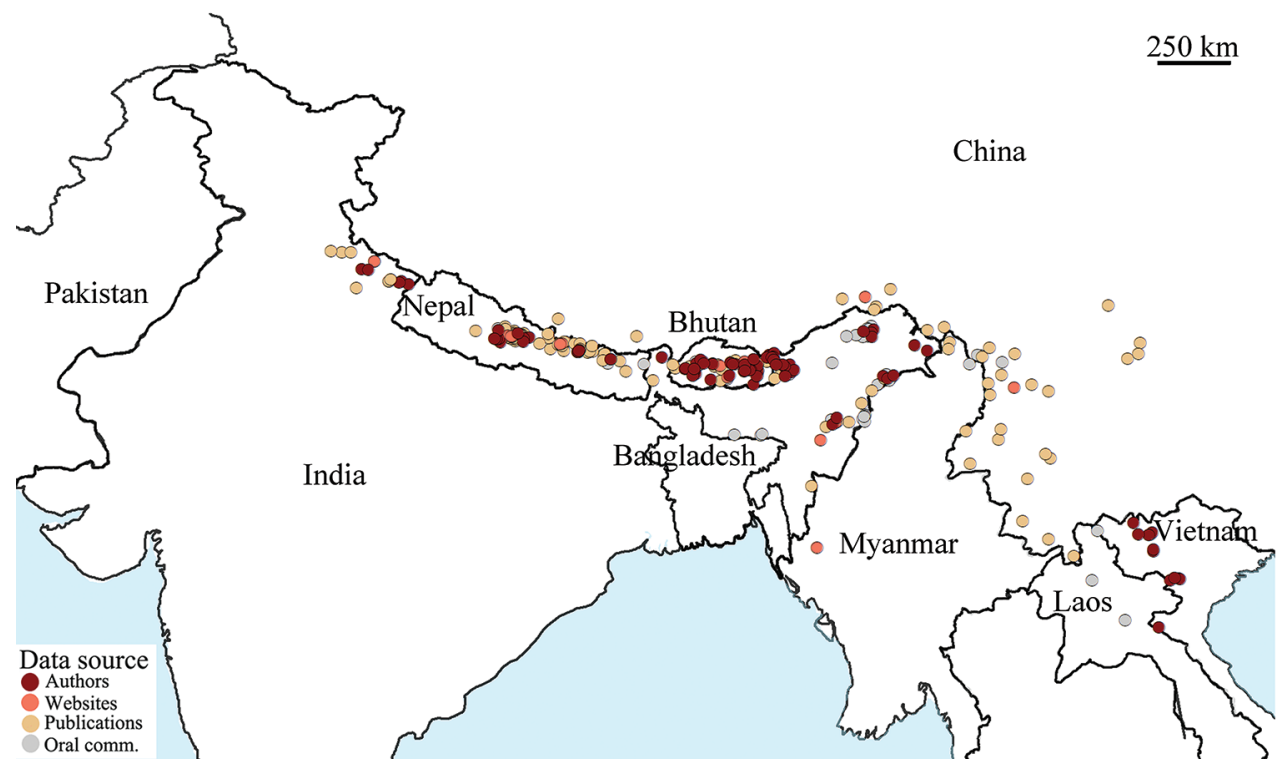

Figure 2. Geographical distribution of Apis laboriosa. Each circle indicates a locality at which a nest of $A$. laboriosa or workers foraging on flowers were found. The color indicates the source of information. Dark red: information collected by one or several of the authors; orange: photos published on websites; tan: information from published papers; and grey: oral reports by colleagues or local people. Scale bar: $250 \mathrm{~km}$.

\section{Sympatric occurrence of Apis laboriosa with Apis dorsata}

In their field trips, the Indian team discovered five sites in three regions of Arunachal Pradesh in northeastern India where A. laboriosa foraged together with its sister species A. dorsata. The regions and sites were: (1) Western Arunachal: West Kameng District, Nag Mandir; (2) Central Arunachal: West Siang District, Tumbin and Siang District, Modi; and (3) Southeast Arunachal: Tirap District, Kala Pahar and Tutnyu (Fig. 4). Additionally, THP observed both species in close proximity at nine sites in northern Vietnam. These are located in five provinces: Hoa Binh, Lao Cai, Lai Chau, Son La, and Yen Bai. The details of these records are presented in Suppl. material 1.

\section{Discussion}

Apis laboriosa inhabits a $2500 \mathrm{~km}$ swath along the southern edge of the Pan-Himalaya region. We have added considerably to the distribution of this species as last presented by Otis (1996). First, we have added many additional localities for this species in Uttarakhand in northern India, the eastern portion of Nepal, all of Bhutan, and much of Arunachal Pradesh in northeastern India, demonstrating that this species is widespread over that region. More importantly, the records we have compiled show range extensions eastward to several provinces in northern Vietnam (first reported there by Trung 


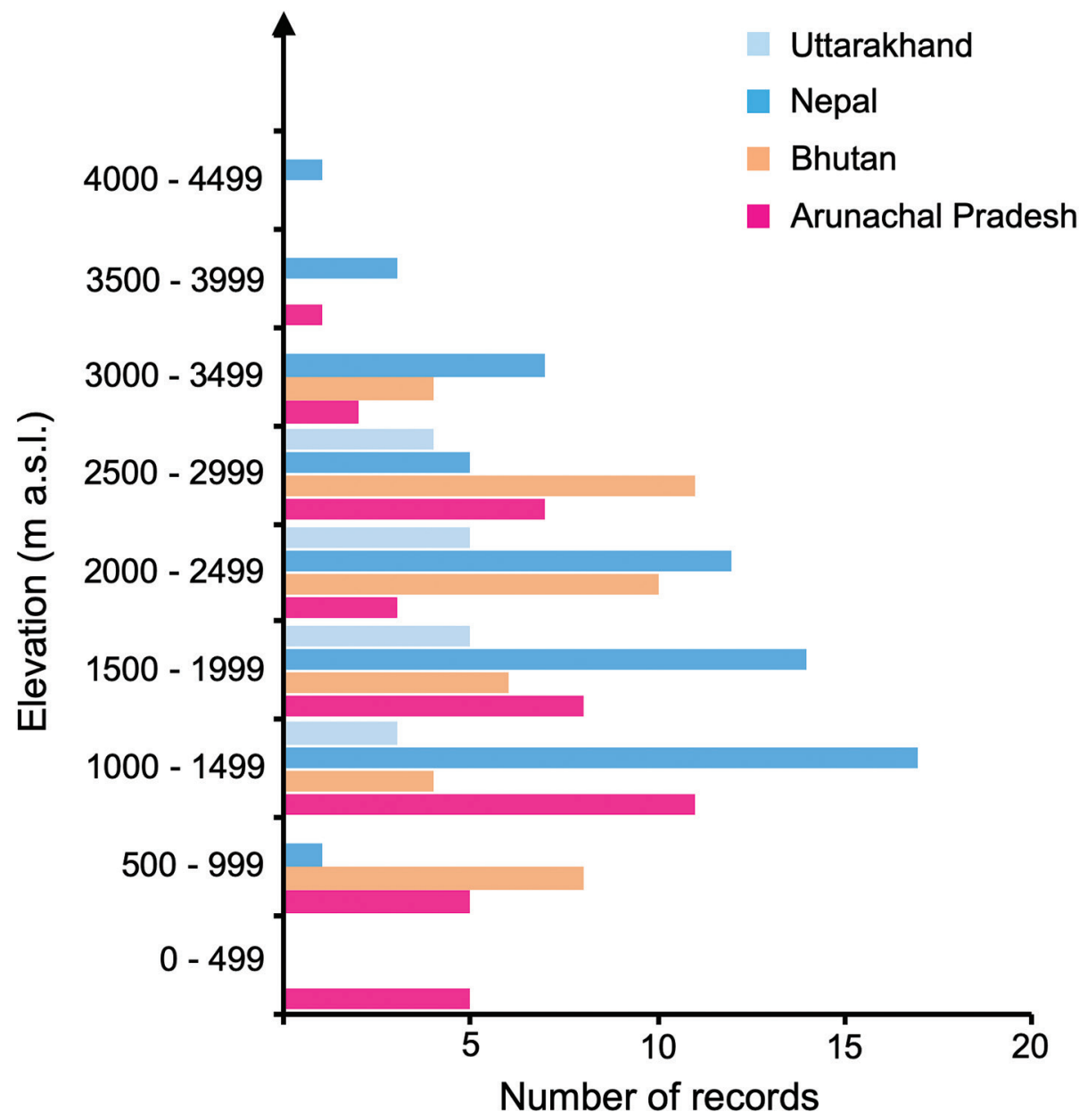

Figure 3. Elevational distribution of A. laboriosa records for Uttarakhand, Nepal, Bhutan and Arunachal Pradesh. 94\% of all records were found between 500-3500 m a.s.l.. The lowest occurrence of $A$. laboriosa was observed in Arunachal Pradesh (229 m a.s.l.), and the highest in Nepal (4267 m a.s.l.). Uttarakhand $(N=17$; range: $1008-2743 \mathrm{~m}$ a.s.l.; mean: $1927 \pm 131 \mathrm{~m})$, Nepal $(N=60$; range: $800-4100 \mathrm{~m}$ a.s.l.; mean: $2036 \pm 103 \mathrm{~m})$, Bhutan $(N=43$; range: 631-3399 m a.s.l.; mean: $2077 \pm 124 \mathrm{~m})$, Arunachal Pradesh ( $N=17$; range: $229-3649$ m a.s.l.; mean: $1620 \pm 143 \mathrm{~m})$.

et al. 1996) and southward for $600 \mathrm{~km}$ in the Arakan Mountains (Patkai Range, Naga Hills, and Mizo Hills of Nagaland, Manipur, and Mizoram) to 21.7N latitude in the Chin Hills of Myanmar. We also report for the first time A. laboriosa from the Shillong Plateau in Meghalaya, India.

Very few $(N=10 ; 6.2 \%)$ collections and observations have been made at locations situated at elevations below $500 \mathrm{~m}$ or above $3500 \mathrm{~m}$ a.s.l. (Fig. 3). Roubik et al. (1985) reported the mean elevations of their observations in central Nepal to be $3143 \mathrm{~m}$ a.s.l. 


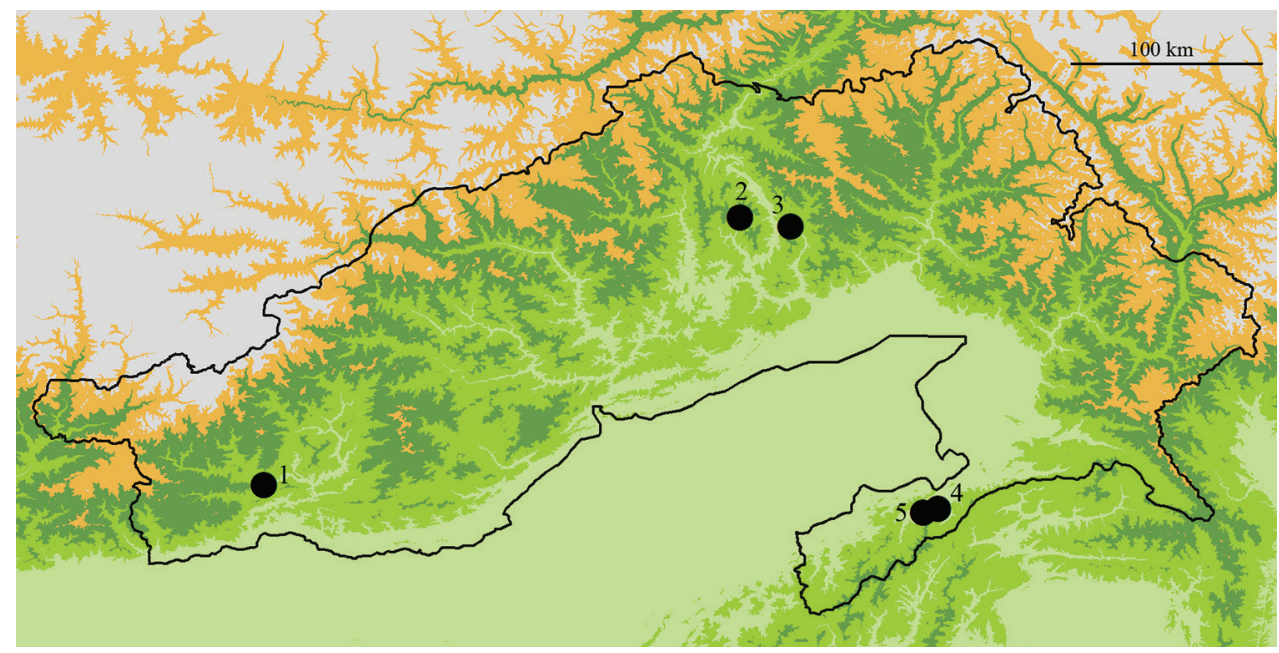

Figure 4. Sites of sympatric occurrence of Apis laboriosa and Apis dorsata in Arunachal Pradesh, India. All five localities (black dots) where we found A. laboriosa and A. dorsata foraging together were below 1500 m a.s.l. (1) West Kameng District, Nag Mandir, 27.203N, 92.561E, 1164 m a.s.l; (2) West Siang District, Tumbin, 28.456N, 94.684E, 356 m a.s.l; (3) Siang District, Modi, 28.487N, 95.087E, $534 \mathrm{~m}$ a.s.l; (4) Tirap District, Kala Pahar, 26.934N, 95.576E ,1470 m a.s.1; (5) Tutnyu, 26.962N, 95.631E, $1060 \mathrm{~m}$ a.s.l. Scale bar: $100 \mathrm{~km}$.

(range from 1800-3800 $\mathrm{m}$ a.s.l), which is much higher than the mean of $2036 \mathrm{~m}$ a.s.l. (range from 800-4100 m a.s.l.) determined from our more complete data set. Our new observations have confirmed the initial observation of Sakagami et al. (1980) that this species occurs at lower elevations in northeastern India than in Nepal (Fig. 3). However, simply mapping localities of nests and foraging bees is static and fails to recognize the dynamic elevational migrations of colonies. Underwood (1990a) reported that $A$. laboriosa colonies abandon most nesting cliffs in fall and spend the winter in combless swarms at lower elevations. By April they have generally recolonized lower elevation nesting cliffs. As the season progresses, colonies continue to move higher in elevations along river valleys during the summer, before they retreat downhill for the winter. The records we have reported (Suppl. material 1) lack sufficient elevational and temporal details to reconstruct patterns of seasonal migrations. However, preliminary observations by NK in Arunachal Pradesh suggest that both $A$. laboriosa and A. dorsata migrate considerable distances along river valleys leading into the mountains during summer months. Detailed observations throughout the seasons along elevational transects are warranted.

Earlier research reported that the altitudinal ranges of $A$. laboriosa and its sister species $A$. dorsata differ substantially (Sakagami et al. 1980; Roubik et al. 1985; Oldroyd and Wongsiri 2006; Hepburn and Radloff 2011). However, Sakagami et al. (1980) commented that these species were both collected at the Denling Forest in Kameng Division, West Arunachal, at an elevation 229 m a.s.l. on 5 May. This rela- 
tively late date in spring suggests these bees were nesting near that site. We have confirmed the sympatric occurrence of these two species in five additional locations within three widely separated regions of Arunachal Pradesh (Fig. 3) and five provinces within northern Vietnam. All of these locations were at altitudes below $1500 \mathrm{~m}$ a.s.l. Interestingly, Joshi and colleagues (Joshi et al. 2008; Joshi et al. 2016) reported these two species as temporally occurring sympatrically at elevations of $2100-2800 \mathrm{~m}$ a.s.l. in Uttarakhand, India; and THP found them co-occurring in nine locations in northern Vietnam. Thus, depending on the environments, both species show variation in their altitudinal range (Underwood 1990a; Woyke et al. 2001; Joshi et al. 2008). More detailed collections and observations of $A$. laboriosa and $A$. dorsata at such sites will be required to verify whether these honey bees hybridize where they occur sympatrically (McEvoy and Underwood (1988). However, till today there is no evidence of intermediate forms where the two species co-occur (Sakagami et al. 1980; Roubik et al. 1985); rather, preliminary morphometric analyses of the specimens from the areas of sympatry in Arunachal Pradesh confirm their differences in size, shape, and colour (NK, unpublished data). If further collections confirm the preliminary conclusion that they maintain their distinctive species-specific characters in sympatry, that will provide additional support for the status of $A$. laboriosa as a distinct species.

Separate from its species status, $A$. laboriosa shows several unique characters that seem to be specific adaptations to living in mountainous habitats. Comparative studies of $A$. laboriosa and $A$. dorsata have shown that they differ in behaviour such as thermoregulation of thoracic temperature during flight (Underwood 1991); minimum temperature for foraging flight activity (Woyke et al. 2012); dorso-ventral abdomen flipping to stabilize body temperature (Woyke et al. 2008) and mating flight times, i.e., early afternoon in A. laboriosa (Underwood 1990b) compared to after sunset in A. dorsata (Tan et al. 1999; Otis et al. 2000). They also differ in other behaviours that may be related to living in high elevation, such as dance communication (Kirchner et al. 1996), pheromonal chemistry (Blum et al. 2000) and defensive body movements (Woyke et al. 2008).

Apis laboriosa is notably absent from the western third of Nepal, from $80.5 \mathrm{~N}$ to 82.6E longitude. This may reflect the relatively dry climate of western Nepal, a lack of collections, or habitat degradation. Field work in several other mountainous portions of Asia may detect this species. These include:

1. northeastern Myanmar (Kumon Range and Gooligong Mountains), eastern Myanmar (much of Shan State), northern Laos (e.g., Annam Highlands and Xiangkhoang Plateau), and possibly extreme northern Thailand (e.g., Doi Pha Hom Pok National Park);

2. the valleys of the Mekong, Yangtze, Yalong, and Dadu rivers that extend into the southeastern edge of the Tibetan Plateau.

3. northeastern Punjab, Pakistan, and western Jammu, India.

Several lines of evidence point to the existence of $A$. laboriosa in Pakistan. Khan et al. (2014) reported several specimens of giant honey bees they collected in Murree, Pakistan 
(33.92N, $73.40 \mathrm{E})$ at an elevation of $-2300 \mathrm{~m}$ a.s.l. as " $A$. dorsata", despite the general understanding that $A$. dorsata lives below $1200 \mathrm{~m}$ a.s.l. elevation in Pakistan (Muzaffar and Ahmed 1990). Unfortunately, the specimens from that study were not retained. Historically, the yellow-rumped honeyguide (Indicator xanthonotus), a bird with an intimate association with A. laboriosa combs (Cronin and Sherman 1976, Underwood 1992, Inskipp et al. 2008), has been observed in Murree (Magrath 1909). Just $60 \mathrm{~km}$ to the east of Murree, giant honey bees collected in Poonch, Jammu, India $(33.82 \mathrm{~N}$, 74.12E), differed markedly in morphometric analyses from other $A$. dorsata specimens from Jammu and the rest of India (Mutharaman et al. 2013). Finding Apis laboriosa in this region would extend its distribution another $400-500 \mathrm{~km}$ northwestward.

\section{Conclusion}

Worldwide pollinator declines have increased the urgency to survey abundances of pollinators and to study their biology and ecology for their conservation. Asian honey bees and in particular species like A. laboriosa, with a restricted distribution in areas difficult to access, are dramatically understudied. Our study provides a revised description of the distribution of the Himalayan giant honey bee, Apis laboriosa. This is a necessary step to revitalize studies on this important pollinator species in the Himalayas (Batra 1996).

Numerous reports on $A$. laboriosa indicate that this honey bee shows specific adaptations to living in high elevation mountainous areas compared to other more tropical honey bee species. Detailed studies on its biology promise to provide interesting insights into the evolutionary history and plasticity of honey bee physiology and social behavior. Locations where $A$. laboriosa and $A$. dorsata co-occur temporally, like those we report in Arunachal Pradesh and Vietnam, are particularly suitable regions for future studies.

\section{Acknowledgements}

We thank M. Hliang (University of Veterinary Science, Yezin, Myanmar), A. Schooffs (Association for Sustainable Beekeeping, Laos), K. Kamp (Agro-Biodiversity Initiative, National Agricultural and Forestry Research Institute, Laos), V. Sarkar (Wildlife Institute of India, Dehradun, India), K. Tan (Xishuangbanna Tropical Botanical Garden, Chinese Academy of Sciences, Kunming, China), K.A. Khan (Unit of Bee Research and Honey Production, King Khalid University, Abha, Saudi Arabia, for information about Pakistan), and X. Zhou and L. Qui (Agricultural University, Beijing, China) for sharing information on locations of bees in the respective countries. M. Messar, J. Narah, N. Jamoh, D. Songthing and I. Haikam helped to collect data in Arunachal Pradesh and Nagaland, India. Numerous people who have posted photographs to iNaturalist and other websites (identified in Suppl. material 1) provided additional data related to their photos and the sites where they were taken. We also thank S. Paiero for helping with photographs of specimens using the Insect Systematics stacking camera system. 
Research and field trips of researchers from RGU and NCBS were supported by funds from Department of Biotechnology Twinning R\&D programme for the NorthEast NER to JC and AB (BT/PR16880/NER/95/333/2015); and institutional funding from National Centre for Biological Sciences (NCBS-TIFR; 12P4167) to AB. NCBS also provided funds for the open access fee. AB acknowledges support of the Department of Atomic Energy, Government of India, under 472 project no. 12-R\&DTFR-5.04-0800. Finally, we would like to thank the reviewers, D.R. Smith and N. Dahanukar, for their useful comments and suggestions.

\section{References}

Arias MC, Sheppard WS (2005) Phylogenetic relationships of honey bees (Hymenoptera: Apinae: Apini) inferred from nuclear and mitochondrial DNA sequence data. Molecular Phylogenetics and Evolution 37: 25-35. https://doi.org/10.1016/j.ympev.2005.02.017

Batra S (1996) Biology of Apis laboriosa Smith, a pollinator of apples at high altitude in the great Himalaya range of Garhwal, India. (Hymenoptera: Apidae). Journal of the Kansas Entomological Society 69: 177-181.

Blum MS, Fales HM, Morse RA, Underwood BA (2000) Chemical characters of two related species of giant honeybees (Apis dorsata and Apis laboriosa): Possible ecological significance. Journal of Chemical Ecology 26(4): 801-807. https://doi.org/10.1023/A:1005476405192

Cao LF, Zheng HQ, Chen X, Niu DF, Hu FL, Hepburn HR (2012) Multivariate morphometric analyses of the giant honey bees, Apis dorsata F. and Apis laboriosa F. in China. Journal of Apicultural Research 51: 245-251. https://doi.org/10.3896/IBRA.1.51.3.05

Chhakchhuak L, De Mandal S, Gurusubramanian G, Sudalaimuthu N, Gopalakrishnan C, Mugasimangalam RC, Vanramliana, Kumar NS (2016) Complete mitochondrial genome of the Himalayan honey bee, Apis laboriosa. Mitochondrial DNA 27: 3755-3756. https:// doi.org/10.3109/19401736.2015.1079891

Cox Jr J (1999) Birds recorded on a west-central Nepal trek, 79 pp. Unpublished. www.digitalhimalaya.com/collections/birdsofnepal/bon.html [see Supplementary file 1: Collection Locality Information]

Cronin Jr EW (1979) The Arun: A Natural History of the World's Deepest Valley. HoughtonMifflin, Boston.

Cronin Jr EW, Sherman PW (1976) A resource-based mating system: the orange-rumped honeyguide. Living Bird 15: 5-32. https://eurekamag.com/research/004/619/004619312.php

Downs CT, van Dyk RJ, Iji P (2002) Wax digestion by the lesser honeyguide Indicator minor. Comparative Biochemistry and Physiology Part A 133: 125-134. https://doi.org/10.1016/ S1095-6433(02)00130-7

Engel MS (1999) The taxonomy of fossil and recent honey bees (Hymenoptera: Apidae; Apis). Journal of Hymenoptera Research 8: 165-196.

Gogoi H, Tayeng M, Taba M (2017) Pan-Himalayan high altitude endemic cliff bee, Apis laborisa Smith (Hymenoptera: Apidae): a review. Proceedings of the Zoological Society 72: 3-12. https://doi.org/10.1007/s12595-017-0234-y 
Gupta SK (2004) Insecta: Hymenoptera. In: Kumar A, Gupta SK, Padmanaban P (Eds) Some Selected Fauna of Gobind Pashu Vihar, Conservation Area Series 18, Zoological Survey of India, Kolkata, 21-28.

Hepburn HR, Radloff SE (2011) Biogeography. In: Hepburn HR, Radloff SE (Eds) Honeybees of Asia. Springer Verlag, Berlin, 51-68. https://doi.org/10.1007/978-3-642-16422-4_3

Inskipp C, Inskipp T, Winspear R, Collin P, Robbin A (2008) Bird survey of the Kanchenjunga Conservation Area, April 2008. Report to Critical Ecosystem Partnership Fund. Bird Conservation Nepal and Royal Society for the Protection of Birds. Bird Conservation Nepal, Kathmandu, and Royal Society for the Protection of Birds, Sandy, UK. http://himalaya. socanth.cam.ac.uk/collections/inskipp/2008_005.pdf

Joshi NC, Joshi PC, Kumar S, Nath P, Singh VK, Mansotra D (2016) Entomofaunal diversity in fruit orchards along the altitudinal gradients of district Nainital, Uttrakhand (India). International Journal of Fauna and Biological Studies 3: 113-120. https://doi. org/10.22271/23940522

Joshi PC, Kumar K, Arya M (2008) Assessment of insect diversity along an altitudinal gradient in Pinderi Forests of Western Himalayas, India. Journal of Asia-Pacific Entomolomology 11: 5-11. https://doi.org/10.1016/j.aspen.2008.02.002

Joshi SR, Ahmad F, Gurung MB (2004) Status of Apis laboriosa populations in Kaski district, western Nepal. Journal of Apicultural Research 43: 176-180. https://doi.org/10.1080/00 218839.2004.11101133

Khan KA, Ansari MJ, Al-Ghamdi A, Sharma D, Ali H (2014) Biodiversity and relative abundance of different honeybee species (Hymenoptera: Apidae) in Murree-Punjab, Pakistan. Journal of Entomology and Zoology Studies 2(4): 324-327.

Kirchner WH, Dreller C, Grasser A, Baidya D (1996) The silent dance of the Himalayan honeybee, Apis laboriosa. Apidologie 27: 331-339. https://doi.org/10.1051/apido:19960501

Kuang BY, Li YC (1985) The genus Apis in China. Chinese Beekeeping 76: 7-9. [Chinese]

Lo N, Gloag RS, Anderson DL, Oldroyd BP (2010) A molecular phylogeny of the genus Apis suggests that the giant honey bee of the Philippines, A. breviligula Maa, and the plains honey bee of southern India, $A$. indica Fabricius, are valid species. Systematic Entomology 35: 226-233. https://doi.org/10.1111/j.1365-3113.2009.00504.x

Maa TC (1953) An inquiry into the systematics of the tribus Apidini or honeybees (Hym.) Treubia 21: 525-640.

Magrath HAF (1909) Bird notes from Murree and the Galis. Journal of the Bombay Natural History Society 19: 142-156.

McEvoy MV, Underwood BA (1988) The drone and species status of the Himalayan honey bee, Apis laboriosa (Hymenoptera). Journal of the Kansas Entomological Society 61: 246-249.

Moore F, Walker F, Smith F (1871) Descriptions of some new insects collected by Dr. Anderson during the expedition to Yunnan. Proceedings of the Zoological Society of London 1871: 244-249.

Mutharaman M, Raju AJS, Vijaymkumar J, Devanesan S, Abrol DP, Viraktamath S (2013) Morphometry of rock bee, Apis dorsata Fabricius. In: Viraktamath S, Fakrudin B, Vastrad AS, Mohankumar S (Eds) Monograph on the morphometry and phylogeography of honey bees and stingless bees in India, 5-13. Network Project on Honey bees and 
Stingless bees. Department of Agricultural Entomology. University of Agricultural Sciences Dharwad, India.

Muzaffar N, Ahmed R (1990) Apis spp. (Hymenoptera: Apidae) and their distribution in Pakistan. Pakistan Journal of Agricultural Research 11: 65-69.

Nidup T, Dorji P (2016) The honey bees (Hymenoptera: Apidae) of Bhutan with a key to the Apis species. Biology Bulletin 2(2): 01-07.

Oldroyd BP, Wongsiri S (2006) Asian Honey Bees. Biology, Conservation, and Human Interactions. Harvard University Press, Boston, MA.

Otis GW (1996) Distributions of recently recognized species of honey bees (Hymenoptera: Apidae; Apis ) in Asia. Journal of Kansas Entomological Society 69: 311-333.

Otis GW, Koeniger N, Rinderer TE, Hadisoesilo S, Yoshida T, Tingek S, Wongsiri S, Mardan M (2000) Comparative mating flight times of Asian honeybees. In: (IBRA/AAA) Proceedings of the $7^{\text {th }}$ International Conference on Tropical Bees: Management and Diversity. $5^{\text {th }}$ Asian Apicultural Association Conference. 137-141.

Raffiudin R, Crozier RH (2007) Phylogenetic analysis of honey bee behavioral evolution. Molecular Phylogenetics and Evolution 43: 543-552. https://doi.org/10.1016/j. ympev.2006.10.013

Roubik WD, Sakagami SF, Kudo I (1985) A note on distribution and nesting of the Himalayan honey bee Apis laboriosa Smith (Hymenoptera: Apidae). Journal of the Kansas Entomological Society 58: 746-749.

Sakagami S F, Matsumura T, Ito K (1980) Apis laboriosa in Himalaya, the little known world largest honeybee (Hymenoptera: Apidae). Insecta Matsumurana 19: 47-77.

Takahashi JI, Rai J, Wakamiya T, Okuyama H (2018) Characterization of the complete mitochondrial genome of the giant black Himalayan honeybee (Apis laboriosa) from Nepal. Conservation Genetics Resources 10: 59-63. https://doi.org/10.1007/s12686-017-0765-6

Tan NQ, Mardan M, Thai PH, Chinh PH (1999) Observations of multiple mating flights of Apis dorsata queens. Apidologie 30(4): 339-346. https://doi.org/10.1051/apido:19990410

Tayeng M, Gogoi H (2018) Insect pollinators of crops and fruits in Arunachal Pradesh, eastern Himalaya: rich diversity in flowers with yellow anther. Proceedings of the Zoological Society 71: 56-62. https://doi.org/10.1007/s12595-016-0185-8

Team NBHM (2015) In search of the giant honey bees $\&$ the honey hunters. Team NBHM travelogue to Khongjiri village Kiphire, Nagaland. Apinews 8: 16-19, Nagaland Beekeeping and Honey. http://www.nbhm.in/apinews/

Trung LQ, Dung PX, Ngan TX (1996) A scientific note on first report of Apis laboriosa F Smith, 1871 in Vietnam. Apidologie 27: 487-488. https://doi.org/10.1051/apido:19960608

Turin, R, Heegaard M, Priemé A (1987) Northern Part of the Indian Subcontinent 87: 30 pp, unpublished. (ww.digitalhimalaya.com/collections/birdsofnepal/bon.html [see Supplementary file 1: Collection Locality Information]

Underwood BA (1990a) Seasonal nesting cycle and migration patterns of the Himalayan honey bee Apis laboriosa. National Geographic Research 6: 276-290.

Underwood BA (1990b) Time of drone flight of Apis laboriosa Smith in Nepal. Apidologie 21: 501-504. https://doi.org/10.1051/apido:19900602 
Underwood BA (1991) Thermoregulation and energetic decision-making by the honeybees Apis cerana, Apis dorsata and Apis laboriosa. Journal of Experimental Biology 157: 19-34. https://doi.org/10.1016/j.jinsphys.2010.08.002

Underwood BA (1992) Notes on the orange-rumped honeyguide Indicator xanthonotus and its association with the Himalayan honey bee Apis laboriosa, J. Bombay Nat. Hist. Soc. 89: 290-295. https://www.biodiversitylibrary.org/part/156573.

Woyke J, Wilde J, Wilde M (2001) A scientific note on Apis laboriosa winter nesting and brood rearing in the warm zone of Himalayas. Apidologie 32(6): 601-602. https://doi. org/10.1051/apido:2001104

Woyke J, Wilde J, Wilde M (2012) Swarming and migration of Apis dorsata and Apis laboriosa honey bees in India, Nepal and Bhutan. Journal of Apicultural Science 56: 81-91. https:// doi.org/10.2478/v10289-012-0009-7

Woyke J, Wilde J, Wilde M, Sivaram V, Cervancia C, Nagaraja N, Reddy M (2008) Comparison of defense body movements of Apis laboriosa, Apis dorsata dorsata and Apis dorsata breviligula honey bees. Journal of Insect Behavior 21: 481-494. https://doi.org/10.1007/ s10905-008-9144-1

\section{Supplementary material I}

\section{Collection locality information}

Authors: Nyaton Kitnya, M.V. Prabhudev, Chet Prasad Bhatta, Thai Hong Pham, Tshering Nidup, Karsing Megu, Jharna Chakravorty, Axel Brockmann, Gard Otis Data type: Excel spreadsheet

Explanation note: Abbreviations as follows - Type of data: Author's observation (1), Photo from website (2), Publications (3), Personal communication (4). Source of Information: Authors' initials- Chet Prasad Bhatta (CPB), Gard Williams Otis (GWO), Karsing Megu (KM), Nyaton Kitnya (NK), M.V. Prabhudev (MVP), Thai Hong Pham (THP), Tsering Nidup (TN); Organizations and Museums: Nagaland Beekeeping and Honey Mission (NBHM), Natural History Museum United Kingdom (NHMUK), National Museum of Natural History, US (USNM), Rijksmuseum of Natural History, Leiden, the Netherlands (RNH). Sakagami et al. (1980) and Underwood (1990a) numbered localities in their papers. Asterisks $\left(^{*}\right)$ indicate sites where $A$. laboriosa and $A$. dorsata occurred sympatrically.

Copyright notice: This dataset is made available under the Open Database License (http://opendatacommons.org/licenses/odbl/1.0/). The Open Database License $(\mathrm{ODbL})$ is a license agreement intended to allow users to freely share, modify, and use this Dataset while maintaining this same freedom for others, provided that the original source and author(s) are credited.

Link: https://doi.org/10.3897/zookeys.951.49855.suppl1 